\title{
Abridged International Perspectives of Technology Education and Its Connection to STEM Education
}

\author{
Geoffrey A. Wright ${ }^{1,}{ }^{*}$, Edward Reeves ${ }^{2}$, John Williams ${ }^{3}$, David Morrison-Love ${ }^{4}$, Fiona \\ Patrick $^{4}$, Jacques Gineste ${ }^{5}$, Ingelore Mammes ${ }^{6} \&$ Grabriele Graube ${ }^{6}$ \\ ${ }^{1}$ College of Engineering, Brigham Young University, Utah, USA \\ ${ }^{2}$ College of Agriculture and Applied Sciences, Utah State University, Utah, 84322, USA \\ ${ }^{3}$ STEM Education Research Group, Curtin University, Perth, Australia \\ ${ }^{4}$ School of Education, University of Glasgow, Glasgow, Scotland \\ ${ }^{5}$ ESPE, Aix-Marseille University, Toulon, France \\ ${ }^{6}$ Centre of Excellence for Technology Education, Universitat Duisburg-Essen, Duisburg, \\ Germany \\ *Corresponding author: College of Engineering, Brigham Young University, Utah, USA. \\ E-mail: geoffwright@byu.edu
}

Received: September 26, 2018 Accepted: November 2, 2018 Published: November 13, 2018

doi:10.5296/ije.v10i4.13704ＵRL: https://doi.org/10.5296/ije.v10i4.13704

\begin{abstract}
STEM (Science, Technology, Engineering, and Mathematics) areas are integral content disciplines in all economies. Although most countries have and continue to ensure quality science (S) and Mathematics (M) education for primary (elementary) and secondary school students, the technology $(\mathrm{T})$ and engineering $(\mathrm{E})$ content areas tend not to be regarded as core to national curricula in the same way that science and mathematics are regarded as essential. This article discusses efforts in various countries to better promote and integrate Technology and Engineering Education (TEE) in schools. This paper highlights common themes and argues that we can learn from each other's efforts in TEE. We argue that dialogue across nations can help us to build international STEM education collaboration networks, better understand the nature of STEM and how to better engage pupils and students in STEM subjects, and work towards gaining inputs to national TEE policy that can leverage positive change.
\end{abstract}

Keywords: Technology and Engineering Education (TEE); curriculum; policy; technological literacy; employment 


\section{Introduction and Context}

STEM has become a catch-all acronym for science and mathematics education in schools and in much educational discourse. However, the $\mathrm{T}$ (technology) and $\mathrm{E}$ (engineering) aspects often become lost or seen as subsidiary to science and mathematics. This matters because STEM education is seen as an area of concern in several nations: STEM education policy is shaped by, and responds to, the perception that STEM knowledge and innovation drives economic growth and recovery in a post-industrial globalised world, despite the evidence for this being mixed (Bozick, Srinivasan \& Gottfried, 2017; Cataldo \& Rodríguez-Pose, 2017). STEM therefore becomes a key element underpinning improvements to national economic capacity through technological and engineering innovation. In addition, and as importantly, it matters because learning STEM subjects can be fulfilling for children and young people, helping to develop a range of conceptual and practical abilities that enhance individual capacity to think critically about STEM subjects and their place in society and to take an informed view about STEM issues.

International literature discusses several challenges for STEM education. Areas of concern are noted as: falling attainment in STEM subjects (Peters-Burton, Lynch, Behrend \& Means, 2014); lack of participation in STEM subjects, particularly for girls and under-represented groups (Bissaker, 2014; Franz-Odendaal, Blotnicky, French \& Joy, 2016; Gorard \& See, 2009); some young people do not see STEM careers as being relevant for them even where they enjoy science and technology (Archer-Ker \& Tomei, 2013; Bøe, Henriksen, Lyons \& Schreiner, 2011; Silver \& Rushton, 2008); and there is perceived lack of confidence in terms of some primary teachers in terms of some STEM subjects (Brigido, Borrachero, Bermejo, \& Mellado, 2013; McGregor, 2014; Murphy, Neill \& Beggs 2007). There is also a lack of clarity around use of the STEM acronym and confusion over the nature of technology and engineering within it (Wong, Dillon \& King, 2016).

In general, much of the STEM literature focuses on mathematics and the physical sciences with less attention as yet paid to the place of technology and engineering in the STEM curriculum. However, a growing body of literature now attests to the educational benefits of studying Technology and Engineering Education (TEE) throughout the school stages, particularly through integrated STEM curricula that include technology and engineering skills (English, King \& Smeed, 2017; Gresnigt, Taconis, van Keulen, Gravemeijer \& Baartman, 2014; Nadelson \& Seifert, 2017). Studying TEE enables children to identify and critically reflect on uses of technology in the world and develop the skills to utilise and create designed artifacts (Sundqvuist and Neilson, 2016). Technology and engineering also offers opportunities for contextualised learning about real world issues, developing skills and habits of mind such as creative problem-solving, visualising, systems thinking, analogical thinking and invention (English et al., 2017; Lewis, 2009). Interesting and valuable work is also being carried out with children in terms of co-creating design for assistive technology (Light, Page, Curran \& Pitkin, 2009), participatory design of learning environments using technology-assisted learning through play (Borum, Brooks \& Brooks, 2015), and broader development of design literacies through involvement for example in spatial design (Green, 2013). These projects demonstrate the potential for innovative learning with and through 
technologies as well as through Technological and Engineering Education. In order to realise this potential teachers need to have knowledge of and confidence in TEE content and pedagogies (Harris and Hofer 2011; Herro \& Quigley, 2017; Voogt and McKenney, 2017).

This review of STEM education in five countries highlights work being done to ensure that the place of technology and engineering is more embedded in school curricula and that the approach to these areas keeps pace with the needs of national and international industry and employment. We make the case that efforts to promote and integrate Technology and Engineering Education (TEE) are important in supporting students to work in globally competitive economies, but also that TEE contributes important knowledge and skills to young peoples' lives. We therefore argue that more needs to be done in the five nations to enable the integration of Technology and Engineering in school curricula.

\subsection{Overview of Case Studies}

In the example from the United States, (author) and (author) highlight the importance of national policy as a driver for the development of TEE, and issues of ensuring coherence of curriculum content and practice when education policy and curriculum content is decided at local (state and district) level. In Australia, (author) focuses on the growth of technology education, and how this growth has led to diversity of practice across schools but also a lack of an agreed definition for STEM. The Scottish example from (author) and (author) notes the recent changes to curriculum and practice in schools, and links to the issues of the 'missing' field of engineering in the school curriculum. (author) then discusses the efforts in France to integrate technology and vocational education as part of general school education. An important element here is how forms of knowledge embedded in STEM are understood, how STEM knowledge can best prepare students for vocational/higher study while also contributing to economic development. Finally, (author) and (author) note the importance in Germany of technological socialisation as a way of engaging people with technology (which remains a marginal subject in the German Secondary school curriculum).

\section{United States of America: Localised Approaches in a Globalised Context}

Technology education has developed from early beginnings in manual training and apprenticeships, through designation as vocational education then industrial arts in the early-mid twentieth century, to use of the current term technology and engineering education. These are more than linguistic shifts: each term denotes changing socio-political and economic contexts as well as evolving policy discourse in response to these contexts. The United States has a significant history of policy support for technology education, and federal legislation has played an important role in shaping past and current approaches to Technology and Engineering Education (TEE) in the United States (Threeton, 2007). This section will first track some of the key aspects of the development of STEM education in the United States, before moving to discuss current aspects of provision.

\subsection{History: from Manual Training and Industrial Arts to Technology Education}

Vocational education has a long history in the United States, and the role of policy in shaping 
approaches to vocational education has been crucial. Important early legislation came with the Morrill Act of 1867 which ensured funding via land grants to set up colleges of agriculture and the 'mechanical arts' (see Maldonado and Saddler, 2008, p.58). Following this, 1900-1917 was a key period in the development of vocational education during which the concept of the industrial arts evolved from manual education in response to industrialisation and the needs of industry and the economy. In 1917 the US government passed the (Smith Hughes) National Vocational Education Act which played a foundational role in advancing the American vocational education system by providing federal funding to pay for the training and salaries of teachers of agricultural and industrial subjects alongside trade and home economics. The George-Reed (1929) and George-Deen Acts (1936) increased federal funding for vocational education in agriculture, home economics, trade and industrial education in response to the Great Depression (Gordon, 2014, p.107). Following the Second World War, the 1946 George-Barden Act increased funding for technical education. Then, in response to the launch of Sputnik in 1957, additional bills were passed - beginning with the National Defense Education Act of 1958 (see Urban, 2010, p.25) - to ensure American students received sufficient scientific and technical training as part of their educational experience.

Many of these acts were passed with specific impetus from particular members of congress. Perhaps the most lasting impact has been felt through Congressman Carl D. Perkins' sponsorship of the 1963 Vocational Education Act which significantly increased federal funding for vocational education. Perkins' importance has been recognised in the naming of subsequent acts such as the 1984 Carl D. Perkins Vocational and Technical Education Act which aimed to improve the quality of technical education as a means of supporting economic growth (Threeton, 2007). In general, the 1980s saw a move from traditional industrial arts (pre-vocational in nature) towards technological education (Herschbach, 1997) fuelled by the publication of the Jackson's Mill Industrial Arts Curriculum Theory (1981). This (re)defined industrial arts as "a comprehensive educational program concerned with technology, its evolution, utilization, and significance; with industry, its organization, personnel, systems, techniques, resources, and products; and their social/cultural impact" (in Foster, 1994, n.p).

\subsection{Current Approaches}

The curriculum and standards which govern the teaching of TEE are directed by individual states: there is no national curriculum in the United States. This approach is reflected in the financing of the system (Department of Education, 2016a). At the time of writing, $87.7 \%$ of education funding comes from state, local, and private sources and $10.8 \%$ comes from federal agencies such as the Department of Education, Department of Health Services, and Department of Agriculture. Although the Federal government is not directly involved in curriculum development, they have some influence. For example, the Department of Education (2016b) has stated that a key part of its mission is to improve attainment for all students by "raising national and community awareness of the education challenges confronting the Nation, disseminating the latest discoveries on what works in teaching and learning, and helping communities work out solutions to difficult educational issues" 
(Department for Education, 2016a, n.p.). In respect of this mission, funding has been made available to individuals, schools and districts for approaches that are likely to make a difference to educational outcomes in keeping with the 'what works' and equal access to education agendas (see Department for Education, 2016b).

Additionally, various organizations - such as the International Technology and Engineering Education Association (ITEEA) - are recognized as national educational organizations though they are not federally funded. These agencies produce guidance for the development of state and district level curriculum policy and content. For example, in 2000, the ITEEA released the Standards for Technological Literacy, Content for the Study of Technology. The 20 standards promoted "technological literacy" (i.e., the ability to use, manage, assess, and understand technology) and identified what school pupils need to know and be able to do to achieve this. ITEEA has also developed the Engineering by Design (EbD) programme (ITEEA, 2016). EbD is an integrative curriculum programme that runs from early childhood education (kindergarten) to the final year of secondary school (' $\mathrm{K}-12$ ' in the United States). It covers all the content areas of STEM, as well as English-Language Arts to support literacies development. The current EbD curriculum is available to states and international partners who join the EbD Network, as are professional development opportunities via ITEEA.

While many states have adopted ITEEA's standards and curricula, others have adopted curricula such as Project Lead the Way (PLTW) for older students, or Engineering is Elementary (EIE) for pupils in elementary (primary) schools. These curricula highlight engagement with engineering, technologies and the sciences as part of real-world contexts, aiming to provide learning that is both constructivist and immersed in critical and creative thinking. They also provide resources for teachers to enable professional learning and classroom resources. Other states have developed their own standards and curriculum suggestions. For example, the Utah State Board of Education has created seven Career Technical Education (CTE) pathways (USBE, 2016). These pathways outline curriculum content and skills in the following areas: agriculture, business and marketing, family and consumer sciences, health sciences, information technology, skill and technical sciences, and technology and engineering education (USBE, 2016). The aim here is for these curricula to bridge between secondary school and tertiary education or employment (USBE, 2016).

\subsection{Challenges}

In spite of its historical importance, and associated congressional acts and funding, TEE is often considered a less important content discipline than other curriculum areas. In part this is due to an inability among some states and districts to evolve TEE from traditional "shop" type curriculum (dating from the 19th and early 20th century manual labour/industrial arts courses). In part, the situation relates to an overwhelming focus on student achievement on standardized tests which has led to many TEE elective courses being eliminated from, or having a reduced presence in, school curricula.

However, in the face of attainment and effectiveness pressures, many school districts and individual schools are developing innovative pedagogy and curriculum content. For example, 
various STEM elementary schools (5-12) have evolved exploratory problem-based learning, where students learn English, Mathematics, History, and Scientific skills within practical real-world contexts. Some secondary schools (13-18) are following suit, promoting robotics, engineering, programming, innovation and creativity, all within contexts where students still learn essential Mathematics, English, Science, and History. However, schools still have to meet the requirements of standardised testing which may not assess the skills developed through innovatory approaches. In negotiating these and other competing demands, teacher knowledge is crucial, and universities should develop teacher education programmes that ensure all teachers are technologically literate (Skophammer \& Reed, 2014; Voogt \& McKenney, 2017). School districts should also provide in-service training to ensure all teachers possess media and technology literacies and skills, particularly if inter- and transdisciplinary approaches are to be encouraged (see Herro \& Quigley, 2017).

In terms of curriculum development, the devolved approach gives flexibility of content and practice but does not encourage broadly agreed, cohesive understandings of STEM education content and pedagogy. As a result, curriculum and pedagogic innovation can become fragmented and partial. One response to these issues would be to base state educational curriculum on a consensus about which technological skills are required in the 21 st Century. The Partnership for 21st Century Skills' (The Partnership for 21st Century Learning, 2015) provides one example of a framework which promotes information, media and technology skills alongside learning and innovation skills (critical thinking, collaboration, communication and creativity). These skills are intended to be the baseline of pedagogical and content practices, rather than a suggestive ideal.

Additionally, it is important that pupils in schools are enabled to take technology and engineering courses and have TEE embedded in the curriculum from early years through to graduation from secondary school. Teaching of TEE should not be limited to 'catch-all' or optional courses. The principles of technology and engineering should be taught as complementary baseline courses that help to contextualise other subjects. This holistic approach has been undertaken in several schools and districts in the United States as an effort to provide a blended integration of STEM education, where the silos of mathematics and science become integrated content into technology education - therefore promoting STEM as a whole, not as individual content strands. Their examples of development and adoption can act as exemplars towards wider system progress.

\section{Australia: from Curriculum Diversity to Curriculum Coherence}

The public education system in Australia is managed individually by five states and two territory governments. The federal government provides some funding to all schools to support specific priorities and strategies, but the majority of school funding comes from state and territory governments. Such localised organisation and management has led to variations in school starting age, curriculum, and division of primary and secondary stages across Australia. Generally, children begin school at ages 5-6, primary school spans 6-7 years and secondary school a further 5-6 years. School is compulsory to age 15: the last two years of 
secondary schooling are post-compulsory. Recent years have seen increased policy emphasis on retaining students at school throughout the post compulsory years. For example, in 2005, the federal government established Technical Colleges to cover education for students in the final two years of secondary schooling. Technical Colleges have an emphasis on vocational education.

\subsection{History of Technological Education in Australia}

Historically there has been much curriculum duplication by the educationally independent states and territories. The first efforts to introduce technology education into the curriculum of the state schools occurred towards the end of the nineteenth century. The 1880's saw a lasting economic depression which created the need for "restructuring the economy in a way that focused attention on the growing need for a higher level of technical and commercial skills in the workforce" (Laird, in Williams, 1996, p.13). As a result, a technical and commercial curriculum was implemented, based on UK models of education, primarily those from Scotland and Wales (Williams, 1996). The new curriculum divided technical and commercial education into commercial, technical and domestic areas at the post primary level. At the end of primary school, pupils identified as being academically capable were directed to schools offering an academic curriculum; those deemed less academically able were directed to technical and domestic schools. The intention for these schools was that they train artisans through a vocational-based curriculum, including subjects that were drawn from the common (gendered) trades of the time: woodwork, metalwork, trade drawing (in the technical schools), and cooking, hygiene and sewing (in the domestic schools). However, technical studies schools never reached the popularity that was expected of them, and by the 1950s rapid economic growth prompted an overabundance of employment opportunities which reduced the need for in-school training in a technology curriculum.

Secondary school subject areas related to technology education evolved not as core but as elective sections of the curriculum. The implication was that these subjects provided learning experiences relevant only for specific groups of students with particular interests or career destinations in mind. This thinking was challenged with the publication in 1994 of nationally agreed curriculum statements by the Australian Education Council (AEC). A Statement on Technology for Australian Schools (Australian Education Council, 1994) provided profiles related to eight learning areas, including technology. Since its publication, all states and territories have established technology learning areas through the development of curriculum, support material and professional development. Although each state adopted their own titles for this new curriculum strand they all contained similar elements with a significant degree of consistency in the definitions of technology used. Technology was defined broadly, and key common elements of the definitions included 'the application of knowledge and resources' used 'to extend human capabilities'. There was strong general agreement that technology involved a process, and that relationships between technology, society and the environment are important.

\subsection{Current Approaches}

Technology Education is delivered through a range of technology related subjects in the 
secondary school including Home Economics, Technical Studies, Computing, Information Technology, Media, Industrial Arts, Design and Technology, Engineering, Agriculture and Business Studies. Probably the most significant aspect of the change is the concept that technology education contributes to all students' general education and therefore should be studied by all in the compulsory years of schooling.

During the first decade of the 21 st century, the national and state governments in Australia collaborated to establish the Australian Curriculum Assessment and Reporting Authority (ACARA). ACARA was tasked with the development of a national curriculum and produced the Australian Curriculum for the Foundation to Year 10 levels in eight learning areas (ACARA, 2017a). Mathematics, Science and Technologies are discrete learning areas, with the Technologies curriculum divided into two sections: Design and Technologies and Digital Technologies. The rationale for Technologies relates generally to the development of skills such as enterprise, collaboration, restoration and sustenance of the environment, and critical and creative thinking through the use of technologies and consideration of their social impact (see ACARA, 2017b). The curriculum is written on the basis that all students will study the two subjects from Foundation to the end of Year 8. In Year 9 and 10, student access to technology subjects are determined by school authorities.

In Design and Technologies, 'students use design thinking and technologies to generate and produce designed solutions for authentic needs and opportunities' (see ACARA, 2017b). The aims (learning outcomes) are to develop the knowledge, understanding and skills to ensure that, individually and collaboratively, students: develop confidence, investigate, generate and critique innovative and ethical solutions, use design and systems thinking, produce designed solutions and understand the roles and responsibilities of people in design and technologies occupations.

\subsection{Challenges}

Technology Education is well established as a core learning area in Australia, although there are still areas for development. For example, in terms of professional development, primary teachers are still becoming familiar with the area, and in secondary schools Technology Education is still evolving from a technical tradition. In addition, there is still significant diversity of practice in schools because states and territories are educationally independent. While this can be seen as a healthy diversity of approaches to the teaching and study of technology, diversity provides challenges related to national curriculum development and teacher support. As schools work toward the development of the national Australian Curriculum, the current level of diversity will decrease.

More broadly, the significant STEM discourse in Australia is mainly driven by politicians and has a workforce planning and economic rationale. However, at present there is no clear definition of STEM, and it is contextually interpreted depending on its application: business and industry, tertiary education, secondary schooling, and elementary schooling. The educational rationale, beyond the notion of integration, is not well developed. In regards to schooling, its application is haphazard and mainly depends on the inclination of individual schools. While there are exciting and interesting projects that schools are developing, 
anecdotal evidence would seem to indicate that technology teachers are not actively pursuing STEM activities, and do not perceive this as an opportunity to promote technology as a key integration and application context for science and mathematics.

Finally, the state technology teacher professional associations are much more active than the national association in promoting technology education. However, with the development of a national curriculum, there may be a reinvigorated role for the national association to play as the development of support material and professional development will have national application.

\section{Scotland: Developing Technologies, Still Seeking Engineering}

The education system in Scotland is distinctive from the other UK nations in terms of its professional culture, policy context, and curriculum. Scotland has a devolved government, where decisions about educational policy are decided by the Scottish Government, rather than the UK parliament in London. In the Scottish state-funded system, there are five educational stages: early years (ante-preschool: birth to 3, and pre-school: age 3-4), primary school (ages: $4 \frac{1}{2}$ and $5 \frac{1}{2}$ to age 12), secondary school (ages: 12-18), Further Education (ages: 16+), and Higher Education. The school leaving age is 16, and every young person leaving school at age 16 receives an offer of 'post-16 learning'. Technology Education is represented within all of these educational stages, though not in the form of discreet subjects until secondary school. The Scottish curriculum focuses on general education (covering a broad spectrum of curriculum content and learning) until the senior secondary phase (secondary years 4-6) when pupils can take technology and engineering type courses.

Technical and vocational education in Scotland has developed not just with respect to the needs of industry and the economy, but as part of a broader set of educational and cultural ideals - most recently, linked to social cohesion and inclusion (see Avis, Canning, Fisher, Morgan-Klein \& Simmons, 2011, p.116). It is, though, the employment and economic needs that are often highlighted in policy. For example, STEM forms an important Scottish Government priority (see Scottish Government, 2014) tied to raising attainment, supporting skills development and improving young people's employability. The urgency of this priority was underlined in the report Education Working for All! (Scottish Government, 2014a). This report emphasizes the importance of strengthening vocational education pathways and school and college partnerships with employers in order to better fit the capabilities of pupils to the 'skills, technology and knowledge requirements of the modern world' (Scottish Government, 2014b, p.4). In 2015, the Scottish Government announced the Making Maths Count initiative, which set up two groups to improve mathematics attainment in primary and secondary schools. The following year (2016) the Scottish Government announced that $£ 1.5$ million would be invested in Scotland-wide educational initiatives to 'boost the delivery' of STEM subjects in Scottish schools (Scottish Government, n.d.).

\subsection{History of Technological Education in Scotland}

Historically, technical and vocational education has developed as a distinctive strand to 
general education in schools, and has been concentrated either in the workplace or in further education colleges. In response to industrialization in the late 1800 s, the Royal Society of Arts introduced 'Technical Instruction' in a range of areas alongside educational examinations in 'Technology' (Society of Arts, 1895). The 19th century also saw the growth of Mechanics Institutes (firstly in Glasgow and Edinburgh in the 1820s) - partly designed for the education of the industrial working classes in technology, and partly as enculturation into the idea of progress through the industrialisation of society (see Laurent, 1984). To these can be added the strong tradition in the late 19th and early 20th centuries of workplace apprenticeships and later, of college-based day-release courses for workers. While these approaches provided a range of opportunities for workplace education and training, the VET system developed as a tracked system (see Raffe, Brannen, Fairgrieve \& Martin, 2001) with vocational and general education generally taking place in different institutions, and seen as appealing to different student groups with different employment outcomes.

Doherty and Canavan (2005) map the modern origins of Scottish Technology Education to the technical subjects developed in the post-WW2 years through to what was collectively termed Technology Education in the late 1970s. These technical subjects sought to develop trade-related manual and technical skills and understanding, giving pupils the option to study woodwork, metalwork, technical drawing, building drawing and applied mechanics up to what was then the O-Level examination taken at the end of 4th year of secondary school. In 1987, the Scottish Education Department introduced the 5-14 Curriculum (primary to junior secondary years). 5-14 sought to move from discrete subjects to integrated areas of study: for example, Technology, Society/Environment and Science were located in the area Environmental Studies. Beyond the primary and early secondary stages, externally assessed courses (developed by the Scottish Qualifications Authority) allowed pupils to study technology subjects including Craft \& Design and Graphic Communication. However, it was difficult to shift the view of these subjects as being anything other than vocational in nature (Canavan \& Doherty, 2007). Gradually from the 1980s on, the false dichotomy between vocational and academic education has been reconsidered to some extent in Scotland as we have moved from a tracked to a more unified system (Raffe et al., 2001). Technical education now has a more central place in schools as something considered educationally beneficial to all.

\subsection{Current Approaches}

Seeing technological subjects as educationally meaningful for all pupils is one feature of Curriculum for Excellence (CfE) (which superceded 5-14 in 2010). Science, mathematics and technology education have a strong presence in CfE, although 'STEM' is not presented in a holistic way, and engineering is still not strongly represented. Technology subjects include Design \& Manufacture, Graphic Communication and Engineering Science. A noted strength of contemporary technology subjects in CfE is the collective breadth of opportunities that they provide for pupils to engage in learning about design, graphics, engineering, societal and practical dimensions of technology. The areas are assessed throughout secondary school, at National Assessment levels 3 and 4 (taken in secondary years 1 and 2) through to Higher or Advanced Higher examinations taken in secondary years 5 and 6. Competencies for 'Design 
and Technology' within the broad general education phase (up to age 14) straddle two context areas in the technologies section of the curriculum: 'technological developments in society' and 'craft, design, engineering and graphics'. After age 14, the courses students are offered cover a wide range of technological and engineering fields and content. These courses are elective courses and are labelled in Scotland engineering science (formerly 'Technological Studies').

There is a strong sense in $\mathrm{CfE}$ that we are shifting from a view of 'technology' to 'technologies' with related areas of these technologies requiring appropriate pedagogies and learning opportunities. CFE's encouragement of interdisciplinary approaches to learning (IDL) is also encouraging. There are early signs that the combination of IDL and increased teacher autonomy is beginning to cultivating new approaches in and around technology education departments. Interdisciplinary and cross-curricular projects between technology subjects, science and other subjects, are being explored in many schools. However, efforts are quite fragmented and it is recognized that IDL is often not well understood (Humes, 2013), even though there have been some specific initiatives to address understanding of engineering and IDL. For example, Engineering the Future was a large-scale project created by the Universities of Glasgow and Strathclyde, industry partners and teachers of Science and Technology that looked at enhancing IDL and exposure to Engineering (MacBride et al., 2010). EtF reported notable successes and gave rise to the national STEM Central website which aims to support learning and teaching 'relating to sciences, technologies, engineering and mathematics' (Education Scotland, 2017, np). However, the extent to which school and pupils successes have been sustained post-initiative are unclear.

\subsection{Challenges}

Technology Education continues to play a strong role within Scottish Education, but more needs to be done to increase awareness of the nature of learning in technology subjects and what these bring to STEM, both discretely and as part of more integrated approaches. While CfE has catalyzed in-subject development for technology education, this has not come without challenge. Pressure to maximize pupil attainment in exams means that externally examined senior phase subjects are implicitly compartmentalizing earlier-phase broad general education technology courses that have the potential to be far more integrative in nature. In addition, more needs to be done to increase knowledge and understanding of engineering in $\mathrm{CfE}$ : the subject is no longer absent from the curriculum but it is still largely missing as a strong and integrated presence. There is scope for technology and engineering to be at the centre of understanding not just interdisciplinary but transdisciplinary approaches to learning in primary and secondary schools (see Gresnigt et al., 2014). Here, learning aims and content are developed across subject boundaries and conceptualised as both pupil-centred and based on real-world themes and projects (Gresnigt et al., 2014, p.53).

In addition, there is a risk that Technology and Engineering may still receive less policy and funding attention than other STEM subjects because Scottish Government concerns focus strongly on attainment in literacy and numeracy in primary school, and underperformance by secondary pupils in Maths and Science (as evidenced in TIMSS and PISA). More broadly, 
technology and engineering tend to be less evident than maths and science in discussions among key STEM groups. For example, between January 2014 and January 2015, the minutes of meetings of the independent STEM Education Committee (STEMEC), set up to enhance STEM in schools following the SEEAG Report (2012), mention the word 'science' 208 times, whilst 'technology' appears on only four occasions. This lack of consideration of technology and engineering, and the stress on sciences and mathematics, does little to reflect either the differing epistemic make-up of the four areas or the value that inclusion of technology and engineering in the curriculum has in enhancing young people's educational experiences.

More widely, there are recognized issues in STEM in terms of workforce representation, teacher supply and demand, and uptake of STEM subjects in tertiary education. There are also still gender issues. Davidson (2016) comments that women make up half the workforce in Scotland but only $1 / 5$ th of the female workforce is employed in STEM subjects $(6 \%$ of these in engineering). Only 3\% of engineering modern apprenticeships in 2014 were taken up by women (Education Scotland, 2015). With scope to do more, it is encouraging that a significant proportion of those currently undergoing Initial Teacher Education (ITE) for secondary school Technology subjects are female. Role models may encourage more girls into underrepresented subjects such as Technological Studies/Engineering Science where they account for only $7 \%$ of pupils (Education Scotland, 2015).

A recent government announcement identified a growing shortage in the overall number of Technology and STEM teachers entering the profession: this will require focused efforts to mitigate this projected shortfall. Finally, the low levels of confidence of Primary School teachers in delivering aspects of science (McGregor, 2014; Murphy, Neill \& Beggs 2007) is mirrored to a large degree in the delivery of Technology Education (Dow, 2011). In 2015, the Scottish Government awarded $£ 930,000$ to the Scottish Schools Education Research Centre (SSERC) to provide CPD that addresses these areas, but efforts in this area must continue.

\section{France: Integrating Vocationalism and STEM}

France has a long tradition of integrating general education with Technology and Vocational Education and Training. The French system is coordinated by the French Ministry of National Education and is mainly funded by the state. State funding levels compare well with other nations - indeed the cost per pupil of upper high school education in France is $20 \%$ higher than the average of other OECD countries (OECD, 2016a). 82\% of primary and secondary schools are state-funded and $17 \%$ are private schools under contract (meaning they adhere to the national curriculum, and the government is responsible for the teachers). The system is highly centralised with national organisation of both school administration and the curriculum. The Ministry of National Education has (as one of its primary responsibilities) the administration of the 32 academic regions of France. Each region is managed by an education officer, designated by the national school administration minister.

The schooling system begins with the optional early education (kindergarten) phase, before moving into the compulsory phase of primary school (école), middle school (college) and 
secondary/high school (lycée). The compulsory phase of schooling lasts from age 5-15. Upon completing compulsory school, students may choose to continue in a general education path (sciences or literature), a technological path (sciences and technology in the domains of industry, tertiary, biotechnology or services) or in a vocational path (professional fields such as services, industry, craft or cottage industry).

At the funding and policy levels, there has been major investment in building, renovating and modernising state high schools, as well as providing materials to support the development and the promotion of new pedagogy. For example, the development of project-based and interdisciplinary approaches and a shift from knowledge-based to competence-based assessment are two manifestations of recent changes.

\subsection{Current Approaches}

The French education system offers a wide range of opportunities to all students, particularly in terms of STEM education. Over $85 \%$ of students take courses in science, technology, engineering, and mathematics; only $15 \%$ of pupils follow courses without STEM, those who choose Literature or Social and Economic Sciences. Mathematics and technology education both play a very special role in the French schooling system. Abstract knowledge is highly valued in French education (Brockmann, Clarke, Méhaut \& Winch, 2008):because mathematics is considered as being at the higher level of abstraction, mathematics education is integral from the beginning of a child's educational experience through schooling and higher education. Further, because technologies are considered as the domain of concrete and practical knowledge, technology education is also valued and integrated into a student's education. Technology Education is largely organised under the name Vocational Education, and is viewed and considered as a structure for helping students ready themselves for industry. More broadly, Technology Education is viewed as supporting pupils to discover the world they live in and understand the world of constructed design objects as artefacts that are integral to society and culture ((author), (date), p.34).

In the 1980's technology education was officially introduced and integrated into the primary and secondary school system partly because the system was 'poorly regarded' in general and partly because employers argued that the system offered too many qualifications that were 'insufficiently geared to the world of work' (Brockmann et al., 2011, p.232). This important reform introduced the distinction between education for all at the compulsory education level (from 5 to 15 years old) and the specialised orientations at high school level (up to the end of secondary school). The primary school approach centres on teaching a common base of knowledge and competences, with a focus on understanding and discovering the world ((author), (date)). The curriculum is designed in such a way that it leads to the emergence of school subjects, such as science, mathematics, and technology. In France, technology teaching is a specific discipline from the middle school (pupils aged 11-15 years) through to the end of secondary.

At the end of the secondary school, Technology Education takes three different forms, aligned with the three different kinds of high schools students will be tracked into: general high school, technological high school, and vocational high school. The general and 
technological high schools are usually on the same campus. About $80 \%$ of students continue to high school; approximately $30 \%$ go to general high school, $20 \%$ go to technological high school, and the final $30 \%$ go to vocational high school. Technology education is a part of sciences in the general high school only for those who choose sciences courses (15\%); pupils who choose literature or economic sciences, do not have any technology education. Science courses in general high school represent $60 \%$ of all courses, and consist of physics, chemistry, biology, engineering, and technology. Recently, a specific course for digital sciences and ICT has been introduced.

The technological high school curriculum is organised around eight different domains: (1) Sciences and Technology of Industry and Sustainable Development, (2) Sciences and Technology of Laboratory, (3) Sciences and Technology of Management, (4) Sciences and Technology of Health and Social life, (5) Sciences and Technology of Design and Applied Arts, (6) Hotel and Restaurant Industry, (7) Techniques of Music and Dance, and (8) Sciences and Technology of Agronomy and Life. Mathematics, technology, and science are domain specific: if a student chooses the domain Sciences and Technology of Industry and Sustainable Development she will receive mathematics, technology, and science content related to careers and skills required to work in that domain.

The vocational high school is a very important part of the French educational system. Historically, just over half of France's students are tracked into a vocational high school after completing compulsory education. The vocational high school is divided into two parts: " $\mathrm{A}$ " Level, and Vocational Diploma. The "A" Level students (30\%) become qualified technicians, while the Vocational Diploma students (20\%) receive a general diploma qualifying them to work in careers as supporting staff or technicians. The curriculum at the vocational high school is based on industry standards, built in close collaboration with professional trade organisations. The science, technology, engineering, and mathematic curriculum is designed to support each vocational orientation.

\subsection{Challenges}

In spite of evident success, some weaknesses appear in the French education system. The first one concerns the low permeability between the different high school tracks. The French system leaves little place for new orientation if a student desires to change paths, for example from an academic career path to a vocational training path. The second issue concerns the relationship between graduation and employment. France exaggerates the importance of advanced degrees, putting a premium on the need to receive an advanced degree (i.e., Masters, Doctorates, etc.), without having sufficient advanced degree career opportunities. IN addition, because the pressure to receive an advanced degree is considered more valuable than technical certifications, the pressures on the primary and junior high levels of school are increasing, forcing the curriculum to be academic preparation focused, rather than general education and skill development focused, where a sense of wonder together with creativity innovation can be encouraged.

In response to these issues, an important reform concerns restructuring compulsory education at both the primary school and junior high school. The French government plans significant 
investment in new curricula, new assessments, and development of new methods for teaching the four major educational aims (reading, writing, numeracy and reasoning). Specific attention has been placed on the sciences, mathematics, and technology education, where instructional methods focus on project-based learning and active investigation approaches. These changes are grassroots, and are influencing teacher training programs, and in-serve teacher training. French educational stakeholders feel that these changes will bring significant changes to student learning, and economic development of France.

However, a recent movement within the educational and political communities is pushing to change the system, where the traditional tracking into a path system will be disrupted. Parents, teachers, and politicians are at the heart of the debate on these changes with strong opposition between those who think that the current French education system cannot continue on this basis of selection by accumulation of academic knowledge, and those who think that the acquisition of knowledge is the only standardized way to structure education. All agree on one point: the educational system must evolve and, if we look at the developments of the last forty years, it must evolve towards a system of education for all throughout basic schooling, followed by an accompaniment of professional orientation and integration. The evolution is, in fact, widely supported by the development of ICT (Information Communication Technology) and the generalisation of their use at school.

Overall, the educational system in France is based on a strong connection between academic instruction and integration into society: this happens particularly at the end of school studies (the diploma level) where pupils are integrated into the labour market. This system has been highly efficient during the full-employment period, because it has helped students make the transition from academic studies into industry by facilitating career readiness and employment. Although this system has proven beneficial to many students, it has also led to inequality, because it causes massive student competition, induces personal and societal stress as students compete for employment, as well as creating and system-wide academic challenges as observed through outcomes in international rankings. As PISA and TIMSS results show, the education system increases inequity between students: the distance between students who have good results and those who have poor results is growing and this differentiation accentuates social division between the advantaged and disadvantaged classes. Indeed, vocational education students are often from lower socio-economic backgrounds (Brandt, 2015).

Another challenge lies in perceptions of vocational education among students. Technological and vocational education is not widely chosen by students at the end of college or is chosen by default. The recent integration of sciences and technology education aims to revalorise vocational education by increasing science content. However, there remains a low rate of uptake (below the EU average) and low consideration of vocational pathways by students, their families, and by the labour market. In addition, challenges have become evident over the past forty years because of the intense pressure caused by large increases in numbers accessing upper secondary school and because of the restructuring of employment in France. Educational change has not kept pace sufficiently with changing economic needs and workplace patterns of employment. The evolution of the French educational system has to 
reconsider the vocational aim of education at all levels, with a more integrative consideration of individual work preparation needs and the economic development needs of France.

\section{Germany: Technological Socialisation and Interdisciplinarity}

The growing importance of technology in all areas of our lives requires the advanced qualification of young professionals through vocational training in order to foster innovation as well as technical and societal progress ((author), (date)). This context also requires technical literacy for everyone so they can cope with changing social and employment contexts and in order for Germany to become a technologically mature society ((author), (date) \& Tuncsoy, 2013). More broadly, technological socialisation is also essential to familiarise people with technology and develop a technological literacy by dealing with it from early childhood throughout their youth up to possible vocational training or a technologically-oriented study course ((author), (date), 2014; Ziefle \& Jacobs, 2009). Education policy in Germany advocates that, as early as preschool and primary school, boys and girls are supposed to be challenged and encouraged in order to build competencies that they will need for future learning in the sciences and technology (GDSU, 2013; (author), (date), 2001; Rohaan, 2009).

\subsection{Current Approaches}

Germany has developed a dual system of academic and vocational education that has largely avoided the issues of status and legitimacy seen in nations that have not adopted a dual system approach. In particular the academic content of vocational education in Germany is strong (Boesel, 2012, p.77). On the whole, the VET system in Germany is well resourced and underpinned by strong VET research capacity in a national network of research centres (OECD, 2016b). Education in Germany is the responsibility of the federal states (Länder). There is a system of (optional) state pre-school (kindergarten) provision, but compulsory education begins from age 6-15 (although many pupils stay in education to age 18).

The different federal state curricula for primary schools mostly subsume technical education under the area of general science or list it under fields such as Humankind/Nature/Culture (Baden-Württemberg), Sculptural Composition (Lower Saxony) as well as Aesthetic Education (Mecklenburg-West Pomerania). General science is an interdisciplinary educational field integrating subjects like nature science, history, geography, technology and domestic science. Advice for strengthening the natural science and technology education from the conference of educational ministers in 2009 provided homogenisation of the different curricula. As a result, technology education and nature science contents are integrated in all 16 curricula but there is no advice about how to present them in an interdisciplinary way.

In contrast, technology education in general schools at lower secondary level is still a marginal subject, despite intensive efforts by technology teachers and interest groups. Technical content is only somewhat represented in the curricula of lower secondary schools. Moreover, structural and didactic approaches are dependent on federal state and school forms 
(Hartmann, Kussmann, \& Scherweit, 2008) and there are few uniform standards. The reason for this is perhaps that the transfer of technical education as a stand-alone subject in German is comparatively new and has not yet had such a long tradition compared to other subjects such as mathematics, science or languages.

Because of this gap between belief in the necessity of technology education and its implementation, different federal states took advice from the KMK (the standing conference of state ministers of education) and established new interdisciplinary subjects in secondary schools. There are different denotations for such integrative education: Human, Nature, Technology, Nature Science and Technology, Nature Science Phenomena, Nature and Technology and Economy, Labour and Technology Graube and (author), (date). Each area has different content and instructional methods, however for comprehensive technology education it is considered important to teach technology education from a homogenous didactical conception. Thus, the Association of German Engineers commissioned the development of an interdisciplinary didactical concept for science and technology ((author), (date)). This concept is based on three different principles: interdisciplinary, problem-solving, and phenomenological learning.

Interdisciplinary learning deals with helping students understand the benefit and methods for making connections between various fields of study. The problem-solving principle promotes the need and skill development of being able to resolve issues that result from the man-made and natural world. The principle of phenomenological learning concerns the need to understand and consider the different perceptions of an issue. The perceptions that need to be considered deal with natural and technological phenomena. An example of what an investigation of natural phenomena would practically look like in a classroom might be researching for example why does cream get stiff when whipped, or why does wind blow. In contrast the technological phenomena curriculum might include a student investigating how an electric beater was design and how it functions, or figuring out how to harness and use flowing water. These examples highlight the direction Germany TEE is going - having a new focus on interdisciplinary learning, problem-solving, exploration of phenomena and investigatory instructional methodology.

\subsection{Challenges}

Recognition that technology education is important for developing citizens in a technology-oriented world, German educational policy has integrated technology education in school curricula, though Technology Education remains as a school subject in some forms of schooling such as the Hauptschule. Technology has become an integrated component of subjects like general science, physics and chemistry. However, each federal state administers the integration of Technology Education differently. There are no standards for all 16 states, thus the level of technology education might vary between states, schools and classrooms. Common educational standards for technology education would help avoid variation and would further a cohesive integrated model that rests on agreed understandings of key principles relating to technology curriculum design, content and practices.

Relating to these issues, the integration of technology education in diverse school subjects is 
often an additive one. However, real world problems are mostly interdisciplinary - the problem here is that the discussion of how to conceptualise interdisciplinarity has not been developed in the education system until recently. A didactical concept for integrating technology education is being developed and has now to be implemented in schools to prepare students for living in a technology-oriented world.

German secondary school teachers generally study two subjects during teacher training: they will not necessarily have depth of knowledge of technology as a curricular or interdisciplinary area: their content and pedagogical content knowledge might not be at an adequate level to enable them to embed technologies successfully. Primary school teachers' technology education is even more lacking and may be ineffectual. Teacher training in technology education is necessary but rarely practiced to any depth. In addition, teachers can develop particular beliefs about the nature of their subject areas (content and pedagogic approaches) and their professional identities in relation to these areas. These beliefs can run deeply and be resistant to change: for example, ((author), (date)) found in her study that the beliefs of physics and chemistry teachers are often not compatible with an interdisciplinary approach. The challenge here is to create teacher training and CPD approaches that would enhance teachers' knowledge and understanding of modern concepts of interdisciplinary STEM education in schools, in ways that connect with, and challenge, their existing beliefs to support new approaches to integrating technology in an interdisciplinary way.

\section{Conclusion}

These case studies from 5 nations highlight both positive aspects of STEM education and some issues, particularly with respect to the place of technologies and engineering in $21 \mathrm{st}$ century curriculum content. The broader issues highlighted are: system design, education governance structures, reaching shared and agreed understandings of the STEM acronym and its component disciplines and the social engineering and classificatory purposes of education can impact on how technology and engineering are viewed in schools and further/higher education. These issues will be explored briefly in this section.

System design in some nations has led to academic and vocational tracks evolving separately (USA, Scotland, Australia). Vocational Education in general, and Technology Education in particular, can suffer perceived lack of status and academic legitimacy where this separate approach is taken (see King, 2012, p.15). Dual system designs (Germany) have more successfully integrated academic, vocational and technical aspects and as a result tend to show more structural coherence in their approach to vocational and technological education (see Boesel, 2012, p.85). Related to system design, the overall governance structures of education systems can have an impact on the shape and cohesiveness of policy, curriculum and practice. The more diffuse are funding, policy and governance structures (e.g. the United States and Australia) the less coherent and cohesive an approach tends to be taken to vocational and technical education curriculum content and assessment, making it harder to maintain quality provision across the nation (see Stone, 2012, p.231). 
Widespread and 'common sense' use of the acronym STEM still raises issues of STEM becoming a 'catch-all' term for related but different disciplines. There remains a need for clearer conceptualisation of the subject areas within the acronym, and use of the term STEM still encapsulates the sciences and mathematics more fully than technology and engineering. Clarity around the philosophical and pedagogic qualities inherent in each of the areas requires further exploration (see Smith \& Barabasch, 2012), as does educators' understandings of interdisciplinary approaches to STEM education. There is also a need to explore what it means to be an exemplary teacher of STEM subjects at elementary and secondary school level (Hoepfl, 2016). In addition, education systems need to ensure high quality research-based programmes of initial teacher education that embed constructs of exemplary teaching in STEM teacher education (Hoepfl, 2016) as well as providing opportunities for students to engage in understanding and practising interdisciplinary learning that integrates STEM, the arts and humanities, to develop meaningful, creative and engaging approaches to learning (see Howes, Kaneva, Swanson \& Williams, 2013; Madden et al., 2013).

The social engineering and sorting functions of education and schooling systems also have an impact on how STEM subjects are viewed in general and how technology and engineering are viewed within STEM. Systems that have not followed a dual approach to schooling (USA, Scotland, France), and/or have traditionally taken a tracking approach to higher levels of study, tend to view the physical sciences and mathematics as being for more academically able pupils and students (Stone, 2012). As a result, technology and other vocational studies tend to be seen as less 'academic' in nature. Attempts to integrate academic and vocational tracks are welcome, but are not without challenge. In addition, links between system design, social engineering, funding and attainment are neither straightforward nor easily understood. While research indicates that attainment is not necessarily raised by either increased funding or an overwhelming stress on high-stakes testing (Klenowski \& Wyatt-Smith, 2011), many governments are loath to move from a 'what works' position. Such political positioning puts pressure on education authorities and schools to show improved attainment, and so teachers can tend to adopt transmission styles of teaching and avoid innovative approaches to classroom practice (Harlen \& Deakin Crick, 2002). In addition, curriculum narrowing may occur (Berliner, 2011; Collins, Reiss \& Stobart, 2010) which makes interdisciplinarity more difficult to encourage and achieve.

These challenges notwithstanding, and given the uncertainties that globalised economics and international political and nation-state instabilities bring, we need to better prepare school pupils for their educational and economic futures. It is time we focus less on teaching to the test, and rather teach our students how to think, how to solve problems, how to build solutions, and how to be innovative. Technology and Engineering Education can encourage these skills in ways that have too long been overlooked. Our case studies show that the featured nations are recognising the educational benefits that TEE can bring, although each has particular political, social and cultural contexts that can both encourage and impede moves towards the integration of TEE in school curricula. 


\section{References}

Archer Ker, L., \& Tomei, A. (2013). What influences participation in science and mathematics? A briefing paper from the Targeted Initiative on Science and Mathematics Education (TISME). London: King's College.

Avis, J., Canning, R., Fisher, R., Morgan-Klein, B., \& Simmons, R. (2011). Vocational education teacher training in Scotland and England: policy and practice. Journal of Vocational Education and Training, 63, 115-127. https://doi.org/10.1080/13636820.2011.566348.

Australian Curriculum, Assessment and Reporting Authority (ACARA). (2017b). Australian Curriculum (v.8.3). Retrieved from http://www.australiancurriculum.edu.au/

Australian Curriculum, Assessment and Reporting Authority (ACARA). (2017b). Technologies.

Retrieved

from

http://www.australiancurriculum.edu.au/technologies/introduction

Berliner, D. (2011). Rational responses to high-stakes testing: the case of curriculum narrowing and the harm that follows. Cambridge Journal of Education, 41, 287-302; https://doi.org/10.1080/0305764X.2011.607151.

Bissaker, K. (2014). Transforming STEM education in an innovative Australian school: The role of teachers' and academics' professional partnerships. Theory into Practice, 53, 5563. https://doi.org/10.1080/00405841.2014.862124.

Bøe, M.V., Henriksen, E.K., Lyons, T., \& Schreiner, C. (2011). Participation in science and technology: young people's achievement-related choices in late-modern societies, Studies in Science Education, 47, 37-72. https://doi.org/10.1080/03057267.2011.549621.

Boesel, D. (2012). Governing VET in the United States: Localization versus centralization. In A. Barabasch \& F. Rauner (Eds.), Work and Education in America (pp.77-100). Dordrecht: Springer. https://doi.org/10.1007/978-94-007-2272-9_5.

Borum N., Brooks E.P., Brooks A.L. (2015). Designing with Young Children: Lessons Learned from a Co-creation of a Technology-Enhanced Playful Learnin Environment. In Marcus A. (Ed.), Design, User Experience, and Usability: Interactive Experience Design (pp. 142-152). Dordrecht: Springer.

Bozick, R., Srinivasan, S., \& Gottfried, M. (2017). Do high school STEM courses prepare non-college bound youth for jobs in the STEM economy? Education Economics, 25, 234-250. https://doi.org/10.1080/09645292.2016.1234585.

Brandt, N. (2015). Vocational training and adult learning for better skills in France. (OECD Economics Department Working Papers, No. 1260.) Paris: OECD Publishing; https://doi.org/10.1787/18151973.

Brigido, M., Borrachero, A.B., Bermejo, M.L., \& Mellado, V. (2013). Prospective primary teachers' self-efficacy and emotions in science teaching. European Journal of Teacher 
Education, 36, 200-217. https://doi.org/10.1080/02619768.2012.686993.

Brockmann, M., Clarke, L., Méhaut, P., \& Winch, C. (2008). Competence-based vocational education and training (VET): the cases of England and France in a European perspective. Vocations and Learning, 1, 227-244. https://doi.org/10.1007/s12186-008-9013-2.

Canavan, B., \& Doherty, R. (2007). Technical education in Scotland: fit for purpose? International Journal of Technology and Design Education, 3, 291-305. https://doi.org/10.1007/s10798-007-9031-7.

Collins, S., Reiss, M., \& Stobart, G. (2010). What happens when high stakes testing stops? Teachers' perceptions of the impact of compulsory national testing in science of 11 year olds in England and its abolition in Wales. Assessment in Education: Principles, Policy and Practice, 3, 273-286. https://doi.org/10.1080/0969594X.2010.496205.

Davidson, J. (2016). The appliance of science: women in STEM. Holyrood. Retrieved from https://www.holyrood.com/articles/inside-politics/appliance-science-women-stem

Di Cataldo, M., \& Rodríguez-Pose, A. (2017). What drives employment growth and social inclusion in the regions of the European Union? Regional Studies. https://doi.org/10.1080/00343404.2016.1255320

Doherty, R., \& Canavan, B. (2005). Mapping reform in Scotland's technology education curriculum: change and curriculum policy in the compulsory sector. Journal of Design and Technology Education, 10, 70-71.

Education Scotland. (2017). STEM Central. Retrieved 30 March, 2017 from https://education.gov.scot/improvement/Pages/sci37-stem-central.aspx

Education Scotland. (2015). Research Briefing: looking at gender balance in STEM subjects at school. Livingston: Education Scotland.

English, L.D., King, D., \& Smeed, J. (2017). Advancing integrated STEM learning through engineering design: Sixth grade students' design and construction of earthquake resistant buildings. The Journal of Educational Research, 110, 255-271. https://doi.org/10.1080/00220671.2016.1264053.

Foster, P.N. (1994). Technology education: AKA industrial arts. Journal of Technology Education, 5 (no pagination). https://doi.org/10.21061/jte.v5i2.a.2.

Franz-Odendaal, T.A., Blotnicky, K., French, F., \& Joy, P. (2016). Experiences and Perceptions of STEM Subjects, Careers, and Engagement in STEM Activities Among Middle School Students in the Maritime Provinces. Canadian Journal of Science, Mathematics and Technology Education, 16, 153-168. https://doi.org/10.1186/s40594-018-0118-3.

Gesellschaft für Didaktik des Sachunterrichts (GDSU) (2013). Perspektivrahmen Sachunterricht. Bad Heilbrunn: Klinkhardt. 
Ginestie, J. (2011). How pupils solve problems in technology education and what they learn. In M. Barak \& M. Hacker (Eds.), Fostering Human Development through Engineering and Technology Education (pp. 171-190). Rotterdam: Sense. https://doi.org/10.1007/978-94-6091-549-9_10.

Ginestié, J. (2009). Thinking about Technology Education in France: A brief overview and some aspects of investigations (R. Watson, Trans.). In J. T. Alister \& M. De Vries (Eds.), International Handbook of research and development in technology education (pp. 31-40). Rotterdam: Sense.

Gorard, S., \& See, B.H. (2009). The impact of socio-economic status on participation and attainment in science. Studies in Science Education, 45, 93-129. https://doi.org/10.1080/03057260802681821.

Gordon, H.R.D. (2014). The History and Growth of Career and Technical Education in America. Illinois: Waveland Press, Inc.

Green, M. (2014) Transformational design literacies: children as active place-makers. Children's Geographies, 12, 189-204. https://doi.org/10.1080/14733285.2013.812305

Graube, G. (2013). Technoscience und Technoscience Education. Zum Paradigmenwechsel didaktischer Bezugsgrößen. Retrieved 19 June 2017 from http://www.digibib.tu-bs.de/?docid=00048892

Gresnigt, R., Taconis, R., van Keulen, H., Gravemeijer, K., \& Baartment, L. (2014). Promoting science and technology in primary education: a review of integrated curricula. Studies in Science Education, 50, 47-84. https://doi.org/10.1080/03057267.2013.877694.

Harlen, W., \& Deakin Crick, R. (2002). A systematic review of the impact of summative assessment and tests on students' motivation for learning. London: EPPI Centre.

Hartmann, E., Kussmann, M., \& Scherweit, S. (2008). Technik und Bildung in Deutschland, Technik in den Lehrplänen der allgemeinbildenden Schulen. Eine Dokumentation und Analyse. VDI-Report 38. Düsseldorf: VDI-Verlag.

Harris, J.B., \& Hofer, M.J. (2011). Technological Pedagogical Content Knowledge (TPACK) in Action: A descriptive study of secondary teachers' curriculum-based, technology related instructional planning. Journal of Research on Technology in Education, 43, 211-229.

Herro, D., \& Quigley, C. (2017). Exploring teachers' perceptions of STEAM teaching through professional development: implications for teacher educators. Professional Development in Education, 43, 416-538. https://doi.org/10.1080/19415257.2016.1205507.

Herschbach, D. R. (1997). From industrial arts to technology education: The search for direction. The Journal of Technology Studies, 23, 24-32.

Hoepfl, M. (2016). The Search for Exemplary Practice. In M. Hoepfl (Ed.), Exemplary 
Teaching Practices in Technology \& Engineering Education. Virginia: Council on Technology and Engineering Teacher Education.

Howes, A., Kaneva, D., Swanson, D., \& Williams, J. (2013). Re-envisioning STEM education: curriculum, assessment and integrated, interdisciplinary studies. A vision research report for the Royal Society. Manchester: University of Manchester. Retrieved from https://royalsociety.org/ /media/education/policy/vision/reports/ev-2-vision-research-re port-20140624.pdf

Humes, W. (2013). Curriculum for Excellence and Interdisciplinary Learning. Scottish Educational Review, 45, 82-93

King, J. (2012). Dilemmas of design: Education versus qualification in the US vocational education system. In A. Barabasch \& F. Rauner (Eds.), Work and Education in America (pp.15-32). Dordrecht: Springer.

Klenowski, V., \& Wyatt-Smith, C. (2012). The impact of high-stakes testing: the Australian story. Assessment in Education: Principles, Policy and Practice, 19, 65-79; https://doi.org/10.1080/0969594X.2011.592972.

International Technology and Engineering Education Association (ITEEA). (n.d.). Mission. Retrieved from https://www.iteea.org/About/Mission.aspx?id=80

International Technology Education Association (ITEEA). (2016). Engineering by Design. Retrieved from https://www.iteea.org/EbD.aspx

International Technology Education Association. (2007). Standards for Technological Literacy. Retrieved from http://www.iteaconnect.org/TAA/PDFs/xstnd.pdf

Kultusministerkonferenz (KMK). (2009): Empfehlung der Kultusministerkonferenz zur Stärkung der mathematisch-naturwissenschaftlich-technischen Bildung. Retrieved from http://www.kmk.org/fileadmin/veroeffentlichungen_beschluesse/2009/2009_05_07-Emp f-MINT.pdf

Laurent, J. (1984). Science, Society and Politics in Late Nineteenth-Century England: A Further Look at Mechanics' Institutes. Social Studies of Science, 14, 585-619; https://doi.org/10.1177/030631284014004004.

Lewis, T. (2009). Creativity in technology education: providing children with glimpses of their inventive potential. International Journal of Technology and Design Education, 19, 255-268. https://doi.org/10.1007/s10798-008-9051-y.

Light, J., Page, R., Curran, J., \& Pitkin, L. (2007). Children's ideas for the design of AAC assistive technologies for young children with complex communication Needs. Augmentative and Alternative Communication, 23, 274-287. https://doi.org/10.1080/07434610701390475.

MacBride, G., Hayward, E.L., Hayward, G., Spencer, E., Ekevall, E., Magill, J., Bryce, A.C., \& Stimpson, B. (2010). Engineering the future: embedding engineering permanently 
across the school-university interface. IEEE Transactions in Education, 53, 120-127.

Madden, M.E., Baxter, M., Beauchamp, H., Bouchard, K., Habermas, D., ... Plague, D. (2013). Rethinking STEM Education: An Interdisciplinary STEAM curriculum. Procedia Computer Science, 20, 541-546; https://doi.org/10.1016/j.procs.2013.09.316.

Maldonado, C., \& Saddler, S. (2008). History of vocational education \& training research in the United States. In Rauner, F., \& Maclean, R. (Eds.), Handbook of Technical and Vocational Education and Training Research. Dordrecht: Springer. https://doi.org/10.1007/978-1-4020-8347-1.

Mammes, I. (2001). Fostering the Interest in Technology. A Survey on the Influence of Technology Education on the Reduction of the Gender Gap with Regard to the Interest in Technology. Frankfurt am Main: Peter Lang Verlag.

Mammes, I. (2014). Zum Einfluss früher technischer Bildung auf die Identitätsentwicklung. tu-Zeitschrift für Technik im Unterricht, 151, 5-11.

Mammes, I., \& Tuncsoy, M. (2013). Technology Education in Primary Schools. In I. Mammes (Ed.), Technical learning in general science (pp. 9-22). Hohengehren: Schneider Verlag.

Mammes, I., \& Schäffer, K. (2014). Anschlussperspektiven? Technische Bildung in der Grundschule und ihrem Übergang zum Gymnasium. In A. Liegmann, I. Mammes \& K. Racherbäumer (Eds.), Facetten von Übergängen im Bildungssystem. Nationale und internationale Ergebnisse empirischer Forschung (pp. 79-94). Münster: Waxmann.

McGregor, D. (2014). Chronicling innovative learning in primary classrooms: conceptualizing a theatrical pedagogy to successfully engage young children in learning science. Pedagogies: An International Journal, 9, 216-232. https://doi.org/10.1080/1554480X.2014.899544.

Murphy, C., Neil, P., \& Beggs, J. (2007). Primary science teacher confidence revisited: ten years on. Educational Research, 49, 415-430. https://doi.org/10.1080/00131880701717289.

Nadelson, L.S., \& Seifert, A.L. (2017). Integrated STEM defined: Contexts, challenges, and the future. The Journal of Educational Research, 110, 221-223. https://doi.org/10.1080/00220671.2017.1289775.

Organisation for Economic Cooperation and Development (OECD). (2016a). Education at a glance: Country note. France. https://doi.org/10.1787/888933398250.

Organisation for Economic Cooperation and Development (OECD). (2016b). Vocational education and training in Germany: Strengths, challenges and recommendations. $\begin{array}{llll}\text { Retrieved } & 31 & \text { March, } & \text { 2017, }\end{array}$ https://www.oecd.org/education/skills-beyond-school/45938559.pdf

Partnership for $21^{\text {st }}$ Century Learning. (2015). Framework for Learning. Retrieved, 29 March, 
2017, from http://www.p21.org/storage/documents/docs/P21_framework_0816.pdf

Peters-Burton, E., Lynch, S., Behrend, T., \& Means, B. (2014). Inclusive STEM highschool design: 10 critical components. Theory into Practice, 53, 64-71. https://doi.org/10.1080/00405841.2014.862125.

Project Lead the Way. (2017). Our K-12 Pathways: Cohesive, Hands-On Learning Experiences. Retrieved from https://www.pltw.org/our-programs

Raffe, D., Brannen, K., Fairgrieve, J., \& Martin, C. (2001). Participation, Inclusiveness, Academic Drift and Parity of Esteem: A comparison of post-compulsory education and training in England, Wales, Scotland and Northern Ireland. Oxford Review of Education, 27, 173-203.

Rohaan, E. (2009). Testing Teacher Knowledge for Technology Teaching in Primary Schools. Eindhoven: Printservice TU.

Scottish Government. (2015). Making Maths Count. Retrieved from http://news.scotland.gov.uk/News/Making-Maths-Count-1c8e.aspx

Scottish Government. (2014a). Education working for all! Commission for developing Scotland's young workforce: final report. Edinburgh: The Scottish Government.

Scottish Government. (2014b). Improving STEM (Science, Technology, Engineering and Mathematics) Education. Retrieved from http://www.gov.scot/Topics/Education/Schools/curriculum/ACE/Science

Scottish Government. (n.d.). $£ 1.5 \mathrm{~m}$ for STEM subjects. Retrieved from http://news.scotland.gov.uk/News/-1-5m-for-STEM-subjects-2393.aspx

Silver, A., \& Rushton, B.S. (2008). Primary-school children's attitudes towards science, engineering and technology and their images of scientists and engineers. Education 3-13, 36, 51-67. https://doi.org/10.1080/03004270701576786.

Skophammer, R., \& Reed, P.A. (2014). Technological Literacy Courses in Pre-Service Teacher Education. The Journal of Technology Studies, 40, 68-80. https://doi.org/10.21061/jots.v40i2.a.2.

Smith, P.L., \& Barabasch, A. (2012). Vocational education then and now: So what's the difference? A dialogue about the philosophy of VET in the United States. In A. Barabasch \& F. Rauner (Eds.), Work and Education in America (pp.141-154). Dordrecht: Springer.

Stone, J.R. (2012). Reflections of US perspectives on VET. In A. Barabasch \& F. Rauner (Eds.), Work and Education in America (pp.231-250). Dordrecht: Springer.

Sundqvist, P., \& Nilsson, T. (2016). Technology education in preschool: providing opportunities for children to use artifacts and to create. International Journal of Design and Technology Education. First online: retrieved from https://doi.org/10.1007/s10798-016-9375-y 


\section{Macrothink}

International Journal of Education

ISSN 1948-5476

2018, Vol. 10, No. 4

Threeton, M. (2007). The Carl D. Perkins Career and Technical Education (CTE) Act of 2006 and the roles and responsibilities of CTE teachers and faculty members. Journal of Industrial Teacher Education, 44 (no pagination). Retrieved from http://scholar.lib.vt.edu/ejournals/JITE/v44n1/threeton.html

Urban, W. J. (2010). More than Science and Sputnik: The National Defence Education Act of 1958. Alabama: The University of Alabama Press. https://doi.org/10.1111/j.1748-5959.2011.00368.x

US Department of Education. (2016a). The federal Role in Education. Retrieved from https://www2.ed.gov/about/overview/fed/role.html

US Department of Education. (2016b). Overview and Mission Statement. Retrieve from https://www2.ed.gov/about/landing.jhtml? src $=\ln$

Utah State Board of Education (USBE). (2016). CTE Pathways Program. Retrieved from http:/www.schools.utah.gov/cte/pathways/

Voogt, J., \& McKenney, S. (2017). TPACK in teacher education: are we preparing teachers to use technology for early literacy? Technology, Pedagogy and Education, 26, 69-83; https://doi.org/10.1080/1475939X.2016.1174730.

Williams, A. (1996). An introduction to technology education. In J. Williams \& A. Williams (Eds.), Technology Education for Teachers (pp. 1-23). South Melbourne: Macmillan Education Australia.

Wong, V., Dillon, J., \& King, H. (2016). STEM in England: Meanings and motivations in the policy arena. International Journal of Science Education, 38, 2346-2366. https://doi.org/10.1080/09500693.2016.1242818.

\section{Copyright Disclaimer}

Copyright for this article is retained by the author(s), with first publication rights granted to the journal.

This is an open-access article distributed under the terms and conditions of the Creative Commons Attribution license (http://creativecommons.org/licenses/by/3.0/). 